\title{
Exploring the framework for Alliance Performance BetWeen Malaysia-Japan Defence MaNUfaCtURING COMPANIES - A CONCEPTUAL STUDY
}

\author{
Chinnasamy Nambi Agamudai Malarvizhi
}

Faculty of Management

Multimedia University, Cyberjaya

Malaysia

malarvizhi@mmu.edu.my

\section{Shamima Raihan Manzoor*}

Faculty of Management

Multimedia University, Cyberjaya

Malaysia

shamimaraihanmanzoor@gmail.com

\section{Sreenivasan Jayashree}

Faculty of Management

Multimedia University, Cyberjaya

Malaysia

jayashree@mmu.edu.my

*Corresponding Author email: shamimaraihanmanzoor@gmail.com

Submission: 20 November $2020 \quad$ Revised:24 December $2020 \quad$ Accepted: 19 January 2021

Peer-review under responsibility of 6th Asia International Conference 2020 (Online) Scientific Committee http://connectingasia.org/scientific-committee/

(c) 2021 Published by Readers Insight Publisher,

Office \# 6, First Floor, A \& K Plaza, Near D Watson, F-70 Markaz, Islamabad. Pakistan,

editor@readersinsight.net

This is an open access article under the CC BY license (http://creativecommons.org/licenses/4.0/). 


\section{A B S T R A C T}

The defence industry is considered an important element of the overall defence capability of any country. Due to this, developing nations across the world have acknowledged the benefits of building a defence industrial base. Hence, there is rising interest in the defence sector to develop a strategic alliance for analysing the role, effect and nature of different types of cooperative behaviour among transnational companies. Hence, this paper intends to explore the antecedents that can help to assess the alliance outcomes for Malaysia-Japan defence companies. The study was based on RBV (resource based view), to discuss the alliance outcomes for both of these countries' defence manufacturing companies that can help to gain access to their resources for the purpose of increasing their value through a suitable combination of resources. Moreover, four organizational success factors of alliance management are also discussed as a part of the framework explored in this study. This study provides meaningful insights for the defence manufacturing company managers and administrators to plan their current and future investments in building up the organizational success factors for alliance performance discussed in this study to achieve competitive advantage and sustainability in the long run.

Keywords: Malaysia, Japan, Defence Manufacturing, Strategic Collaboration

\section{R E S E A R C H H I G H L I G H T S}

The present study is based on RBV ("Resource Based View"). RBV, as proposed by Lacity and Cocks (2008), turns over on the resources and/or capabilities that a firm possesses. In quite the same way, Rantakari $(2010$, p.23) sees the resource based view working in the cases of firms "where the outsourcing decision is based on the client company's abilities to invest in internal capabilities and thus sustain competitive advantage". Hence, the resources are the main elements of their performance, which also amount to their capability. Besides these resources/capabilities may add to a competitive advantage of the firms as well, which can also help their sustainability. In the theoretical explanations of the $\mathrm{RBV}$, there are explicit references to the significance of strategic alliances as well as the prerequisites for firms' success. Moreover, organizational culture and organizational structures as particularly critical "organizational capital resources" (Barney, 1986, p.663).

\section{G R A P H I C A L A B S T R A C T}

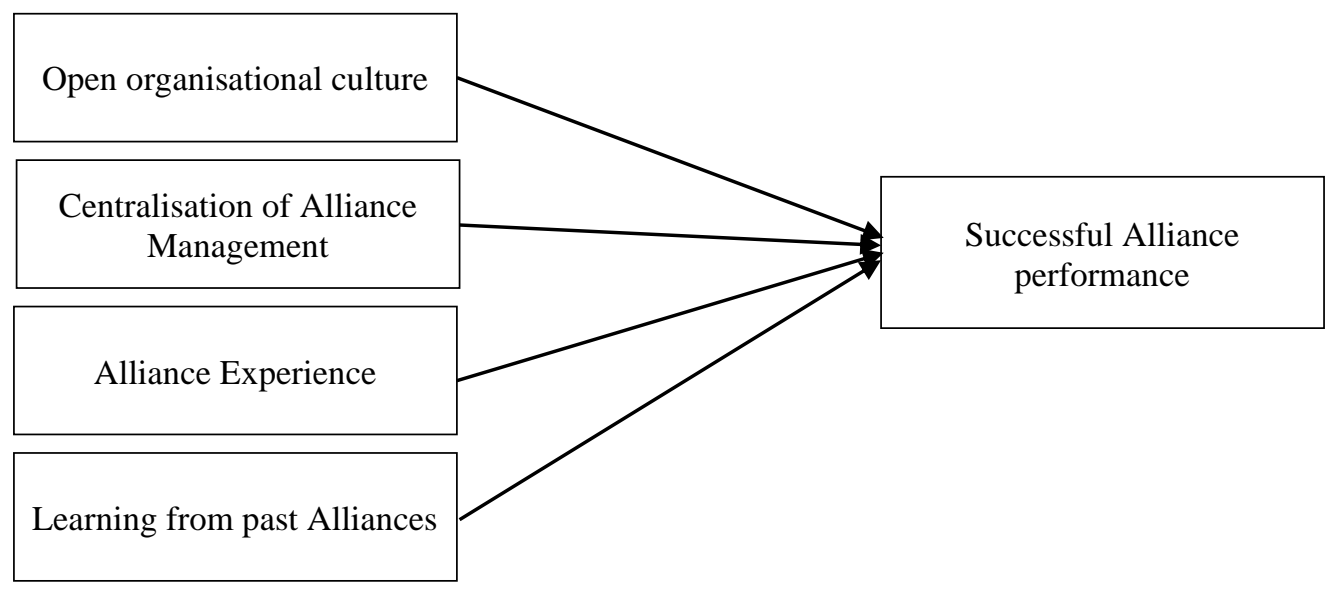




\section{Research Objectives}

Malaysia and Japan already have good bi-lateral relationships throughout the past decades which is remarkable also due to the impact of 'Look East Policy'. Hence, exploring the framework on strategic alliance success between these two countries' defence manufacturing companies can be a timely endeavour. As come under the scope of international business and transnational politics (or geopolitics, to be more precise), "Strategic alliances" are voluntary business activities between two or more companies geared towards a specific objective of improving the competitive position and designed for a medium-term period (Gulati, 1998, p.293; Das \& Teng, 2000, p.33). This study intends to explore the antecedents of alliance performance framework to enhance the capabilities of defence manufacturing companies through collaboration between Malaysia and Japan.

\section{Methodology}

This study uses a qualitative research method of discussions and interview with the purposelty targeted group or individuals in the selected companies. The managerial heads and experts of the defence manufacturing companies working in Malaysia are interviewed to get the insights regarding their existing resources, organisational culture, organisational structure, alliance experience that are helpful to establish successful alliance performances with Japan Defence manufacturing companies. The interviews are focused on aspects such as how dynamic and entrepreneurial the business unit is; whether business unit accentuates the growth and the acquisition of new resources; having support for the management of R\&D alliances through a central authority; how many research and development (R\&D) alliances the particular defence company/business units have been involved in over the past five years; the level of satisfaction with the overall performance of their R\&D alliances with their counterparts, that is Japanese defence Manufacturing companies, etc.

\section{Findings}

The present study offers meaningful descriptive insights into the factors that drive the success of the alliance performance between transnational defence manufacturing company such as Malaysia and Japan. The factors discussed in this study that simultaneously affect multiple alliances of a defence manufacturing company and are therefore of major importance to the company in its overall impact. Managers invest continuously in building up the organizational success factors discussed in this study. Overall an effort was made based on the RBV to identify a comprehensive set of success factors on an organizational level. Nevertheless, with the help of further theoretical approaches, such as the transaction cost theory, future research projects could aim to identify other organizational factors influencing the success of the alliance for transnational defence manufacturing companies. 


\section{Acknowledgement}

The authors of this paper are thankful to the Sumitomo Corporation, Japan for their support in funding this project administered by Multimedia University, Malaysia (MMUE/190016 Japan and Malaysia: Exploring Collaboration in Defence Manufacturing Capabilities).

\section{References}

Barney, J.B. (1986). Organizational culture: can it be a source of sustained competitive advantage? Academic Management Review 11(3), 656-665.

Das, T.K. \& Teng, B. (1998). Between trust and control: developing confidence in partner cooperation in alliances. Academy of Management Review, 23(3), pp. 491-512.

Gulati, R. (1998). Alliances and networks. Strategic Management Journal, 19(4), 293-317.

Lacity, M.C. \& Willcocks, L.P. (2003). Sourcing Reflections - Lessons for Customers and Suppliers. Wirtschaftsinformatik 45(2), 115-125.

Rantakari, L. (2010). Governance in business process outsourcing: case study on call center outsourcing, Aalto University School of Economics.

\section{Author's Biography}

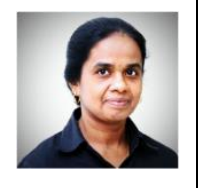

Dr Malarvizhi has more than 18 years of teaching and research experience in Economics, Environment and Health issues, Knowledge Management and Tourism Development. She regularly publishes in journals and presents at international conferences. She has supervised many PhD research scholars as well as Masters and undergraduate students.

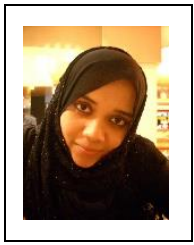

Ms Shamima Raihan Manzoor has more than 9 years of teaching and research experience in Marketing, Higher Education, Business Administration, and Health Management. She regularly reviews and publishes articles in indexed journals and presents at international conferences.

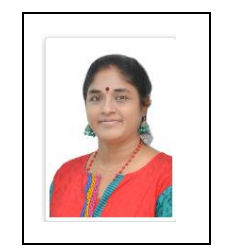

Dr Jayashree's specialization is Total Quality Management (TQM). She has teaching and research experience of more than 18 years. She has published many research papers in the fields of ISOEMS, TQM, Tourism, Waste Management, and has achieved several FRGS grants. 